$\begin{array}{rr}\text { JURNAL } & \\ \text { FIT(1)PATOLOGI } & \text { Volume } 17, \text { Nomor } 1, \text { Januari } 2021 \\ \text { I N DO ON E IA } & \text { Halaman } 19-27 \\ \text { ISSN: } 0215-7950 & \text { DOI: } 10.14692 / \text { jfi.17.1.19-27 }\end{array}$

\title{
Keparahan Penyakit Blas Pyricularia oryzae dan Analisis Gen Virulensi Menggunakan Metode Sequence Characterized Amplified Region
}

\section{Severity of Blast Disease and Analysis of Virulence Gene Using Sequence Characterized Amplified Region Method}

\author{
Gilang Kurrata, Tutik Kuswinanti*, Andi Nasruddin \\ Universitas Hasanuddin, Makassar 90245
}

\begin{abstract}
ABSTRAK
Penyakit blas padi yang disebabkan oleh cendawan Pyricularia oryzae (teleomorph: Magnaporthe oryzae) merupakan salah satu penyakit penting pada pertanaman padi di dunia, termasuk di Indonesia. Penggunaan varietas tahan merupakan cara penanggulangan penyakit blas yang murah, efisien dan aman dari risiko pencemaran pestisida. Namun ketahanan suatu varietas padi terhadap penyakit blas hanya dapat dimanfaatkan beberapa tahun saja disebabkan oleh kompleksitas patogen yang dengan mudah dapat mematahkan ketahanan varietas terutama bila ketahanan varietas ditentukan oleh hanya satu gen dominan. Penelitian ini bertujuan untuk mengetahui keparahan penyakit blas dan variasi genetik dari isolat-isolat $P$. oryzae dari Kabupaten Maros serta hubungan tingkat keparahan penyakit dengan ragam haplotipe yang diperoleh sebagai dasar rekomendasi pengendalian dengan varietas tahan yang sifatnya spesifik lokasi. Pengamatan keparahan penyakit blas menggunakan standard evaluation system for rice dilakukan di 8 lokasi lahan petani di Kabupaten Maros Sulawesi Selatan pada bulan Juni sampai September 2019. Analisis keragaman genetik dilakukan menggunakan primer spesifik penyandi gen virulensi ( $P w l 2, E r g 2$ dan Cut1). Tingkat keparahan blas tertinggi diamati pada var. Mekongga sebesar 42.12\% di Kecamatan Simbang dan 23.33\% di Kecamatan Maros Baru. Di Kecamatan Tanralili (var. Inpari-7) dan Kecamatan Mandai (var. Ciherang) tingkat keparahan hanya 7.6\% dan 7.88\%. Sebanyak 15 isolat $P$. oryzae diperoleh dari 8 kecamatan di Kabupaten Maros. Analisis keragaman genetik menggunakan 3 primer menunjukkan adanya 5 haplotipe yang berbeda, yaitu haplotipe A-000 (4 isolat), C-011 (3 isolat), D-111 (2 isolat), F-110 (3 isolat) dan G-100 (3 isolat).
\end{abstract}

Kata kunci: analisis molekuler, haplotipe, padi, Pyricularia oryzae, tingkat keparahan

\begin{abstract}
Rice blast disease caused by the fungus Pyricularia oryzae (teleomorph: Magnaporthe oryzae) is one of the important diseases in rice cultivation in the world, including Indonesia. The use of resistant varieties is a way to deal with blast disease since it is cheap, efficient and safe from the risk of pesticide pollution. However, the resistance of a rice variety to blast disease can only be utilized for a few years due to the complexity of pathogens which can easily break down the resistance of a variety, especially if their resistance is determined only by one dominant gene. The aims of this research was to determine the severity of blast disease and genetic variation of P. oryzae isolates from Maros District and the relationship between disease severity and haplotype variety obtained as the basis for recommendations
\end{abstract}

*Alamat penulis korespondensi: Departemen Hama dan Penyakit Tumbuhan, Fakultas Pertanian, Universitas Hasanuddin, Jalan Perintis Kemerdekaan KM. 10 Makassar 90245.

Tel: 081342562411, surel: koeswinanti@yahoo.com. 
for control with site-specific resistant varieties. The severity of blast disease was observed using the Standard Evaluation System for Rice was carried out in 8 locations (different sub-districts) in Maros District, South Sulawesi from June to September 2019. The pathogen's genetic diversity was determined using specific primers, coding the fungus virulence genes namely Pwl2, Erg2 and Cut1. The highest leaf blast intensity was observed on var. Mekongga in Simbang sub-district (42.12\%) and Maros Baru subdistrict (23.33\%). In Tanralili sub-district (Inpari-7) and Mandai sub-district (var. Ciherang) leaf blast intencity were $7.6 \%$ and $7.88 \%$ respectively. A total of 15 isolates of $P$. oryzae obtained from 8 subdistricts in Maros. Analysis of genetic diversity showed found 5 different haplotypes, namely haplotype A-000 (4 isolates), C-011 (3 isolates), D-111 (2 isolates), F-110 (3 isolates) and G-100 (3 isolates).

Key words: blast intencity, haplotype, molecular analysis, Pyricularia oryzae, rice

\section{PENDAHULUAN}

Cendawan Pyricularia oryzae dapat menginfeksi tanaman padi di semua tahap pertumbuhan di bawah lingkungan yang kondusif (Scardaci et al. 1997). Kerugian akibat penyakit ini mencapai kisaran 10$30 \%$ dari panen padi tahunan (Skamnioti dan Gurr 2009). Wang et al. (2014) melaporkan penurunan hasil padi di Jepang akibat penyakit blas sekitar $60 \%$, di Brasil pernah mencapai $100 \%$, India $7.5 \%$, Korea $8 \%$, Cina 14\%, Filipina $67 \%$, Vietnam $60 \%$, Italia $24 \%$ dan Iran 50\%, sedangkan di Indonesia pada tahun 2015 mencapai 46924 ha atau 9.25\% dari total luas areal pertanaman padi (Direktorat Jenderal Tanaman Pangan 2015). Di Sulawesi Selatan, total luas serangan penyakit blas pada 24 kabupaten/kota dari tahun 2004-2013 mencapai 12056 ha. Total luas serangan blas tertinggi terdapat pada 3 kabupaten yaitu Kabupaten Sinjai (5993 ha), Kabupaten Maros (1814 ha) dan Kabupaten Bone (1023 ha) (BPTPH Sulsel 2014).

Pada awalnya pengendalian penyakit blas padi menggunakan varietas tahan terbilang efektif. Namun, varietas tahan hanya efektif dalam jangka pendek karena munculnya ras $P$. oryzae baru (Utami et al. 2006). Munculnya ras baru $P$. oryzae sebagai akibat perubahan genetik secara alami yang terjadi karena adanya berbagai faktor tekanan lingkungan dan faktor inang (Kang dan Lee 2000). Menurut Taheri dan Irannejad (2014) variasi dalam patotipe dan struktur populasi patogen ini sangat dipengaruhi oleh kondisi geografis suatu wilayah. Ras-ras patogen dapat berubah sifat virulensinya dalam waktu singkat bergantung pada inang dan pengaruh lingkungan (Utami et al. 2006).

Keragaman genetik dalam biologi populasi patogen dapat diketahui di antaranya melalui pemantauan keragaman fisiologi ras (patotipe) dan keragaman genetik (haplotipe). Keragaman patotipe diklasifikasi berdasarkan reaksi tanaman diferensial yang masing-masing memiliki gen yang mampu membedakan patogenesitas isolat yang diuji (Hayashi dan Fukuta 2009; Fukuta et al. 2009), sedangkan keragaman haplotipe salah satunya diketahui melalui analisis patogen dengan marka molekuler polymerase chain reaction (PCR) (Leung et al. 1993).

Penggunaan penanda spesifik berbasis PCR yang terkait dengan virulensi seperti Cut1, Erg2 dan $P w l 2$ dapat digunakan untuk mendeteksi variasi genetik patogen tanaman termasuk mengetahui mekanisme interaksi tanaman padi dengan blas (Soubabere et al. 2005; Lestari et al. 2014). Berdasarkan hal tersebut maka diperlukan penelitian tentang analisis keragaman genetik $P$. oryzae di Kabupaten Maros yang dapat dimanfaatkan dalam pengembangan perakitan varietas tahan yang sifatnya "spesifik lokasi".

\section{BAHAN DAN METODE}

\section{Pengamatan Tingkat Keparahan Penyakit Blas dan Pengambilan Sampel di Lapangan}

Pengamatan dilakukan di lahan yang menunjukkan gejala serangan $P$. oryzae. Pengambilan sampel di tiap lokasi menyesuaikan kondisi pertanaman di lapangan 
dan tidak mensyaratkan keseragaman umur dan varietas tanaman. Parameter yang diamati ialah luas bercak penyakit blas pada daun padi berdasarkan metode IRRI (2013). Selanjutnya untuk mengetahui kategori tingkat serangannya, hasil penghitungan keparahan penyakit blas daun disesuaikan dengan kategori skala serangan berdasarkan Akhsan dan Palupi (2015) sesuai Tabel 1.

\section{Isolasi dan Identifikasi Cendawan P. oryzae}

Identifikasi cendawan blas dilakukan dengan mengamati morfologi koloni berupa warna dan tampilan permukaan setiap isolat pada medium agar-agar dekstrosa kentang (ADK). Biakan cendawan dipertahankan dalam 12 jam gelap untuk membantu sporulasi, kemudian morfologi konidia diamati dari masing-masing isolat. Cendawan P. oryzae dapat diidentifikasi dengan adanya konidia yang berbentuk pyriform mirip gada berwarna abu-abu hingga hialin dan umumnya memiliki 2 septa, namun kadang-kadang juga ditemukan 1 atau 3 septa (Bonman et al. 1986; Srivastava et al. 2014).

Analisis Gen Virulensi Cendawan $P$. oryzae Menggunakan Metode Sequence Characterized Amplified Region (SCAR)

Isolasi DNA genom isolat cendawan P. oryzae dilakukan dari kultur miselium cendawan. Ekstraksi DNA mengikuti prosedur gSYNC ${ }^{\mathrm{TM}}$ DNA (Geneaid Biotech Ltd Taiwan).

Pengamatan dilakukan pada pola pita DNA hasil amplifikasi pada tiap amplikon primer dengan ukuran berkisar $1440 \mathrm{pb}$ untuk gen Erg2, 800-900 pb untuk gen Pwl2 dan 800-1730 pb untuk gen Cut1. Reaksi PCR dilakukan pada volume total $25 \mu \mathrm{L}$ yang mengandung 5 ng DNA, 1 pmol $\mu \mathrm{L}^{-1}$ primer forward dan reverse (Tabel 2), $12.5 \mu \mathrm{L}$ enzim Go Taq ${ }^{\circledR}$ Green Master Mix dan $5.5 \mu \mathrm{L} \mathrm{H}_{2} \mathrm{O}$. Amplifikasi dilakukan menggunakan mesin thermal cycler GeneAmp PCR System 9700 (Applied Biosystem USA) dan dijalankan siklusnya mengikuti Soubabere et al. (2005) dan Reflinur et al. (2005). Elektroforesis produk amplifikasi untuk mengidentifikasi amplikon tiap primer sesuai ukuran pita DNA dilakukan pada gel agarosa $1 \%(w / v)$ yang ditambahkan $6 \mu \mathrm{L}$ florosafe DNA stain sebagai pewarna DNA alternatif pengganti ethidium bromide $(\mathrm{EtBr})$ dengan tegangan listrik 100 Volt selama 40 menit. Hasil amplifikasi yang muncul untuk setiap primer dari masingmasing isolat dikategorikan, yaitu 1 (ada pita DNA) dan 0 (tidak ada pita DNA). Selanjutnya data ini digunakan untuk mengelompokkan isolat-isolat uji menjadi beberapa haplotipe berdasarkan kombinasi tiga jenis gen (Erg2, Pwl2 dan Cut1) pada isolat-isolat yang diuji (Tabel 3).

\section{HASIL}

\section{Tingkat Keparahan Penyakit Blas Padi}

Hasil pengamatan luas bercak penyakit blas di pertanaman padi sawah pada umur tanaman berkisar 41-75 HST di 8 Kecamatan di Kabupaten Maros menunjukkan keparahan yang bervariasi, yaitu 6.57-42.12\% (Tabel 4). Keparahan penyakit blas tertinggi terjadi di Kecamatan Simbang pada var. Mekongga 70 HST (42.12\%) dengan kategori berat, diikuti di Kecamatan Maros Baru pada var. Mekongga 41 HST (23.33\%), di Kecamatan Bantimurung

Tabel 1 Kategori skala serangan pada daun (Akhsan dan Palupi 2015)

\begin{tabular}{lcc}
\hline Skala & Luas gejala penyakit & Kategori \\
\hline 1 & $1-5 \%$ dari luas daun & Tahan \\
3 & $5-11 \%$ dari luas daun & Ringan \\
5 & $>11-25 \%$ dari luas daun & Sedang \\
7 & $>25-75 \%$ dari luas daun & Berat \\
9 & $>75-100 \%$ dari luas daun & Puso
\end{tabular}

Tabel 2 Sikuen nukleotida primer yang digunakan untuk mengamplifikasi gen virulensi

\begin{tabular}{|c|c|}
\hline $\begin{array}{l}\text { Lokus } \\
\text { Primer }\end{array}$ & Urutan basa Primer ( $\left.5^{\prime}-3^{\prime}\right)$ \\
\hline \multirow{2}{*}{ Erg2 } & F: GCAGGGCTCATTCTTTTCTA \\
\hline & R: CCGACTGGAAGGTTTCTTTA \\
\hline \multirow{2}{*}{$P w l 2$} & F: TCCGCCACTTTTCTCATTCC \\
\hline & R: GCCCTCTTCTCGCTGTTCAC \\
\hline \multirow{2}{*}{ Cut1 } & F: TATAGCGTTGACCTTGTGGA \\
\hline & R: TAAGCATCTCAGACCGAACC \\
\hline
\end{tabular}

Ket: F, Forward; R, Reverse. 
Tabel 3 Haplotipe cendawan blas berdasarkan 3 gen virulensi

\begin{tabular}{lccc}
\hline & \multicolumn{3}{c}{ Gen penyandi virulensi } \\
\cline { 2 - 4 } Haplotipe & $\begin{array}{c}P w l 2 \\
(800-900 \mathrm{pb})\end{array}$ & $\begin{array}{c}\text { Erg2 } \\
(1440 \mathrm{pb})\end{array}$ & $\begin{array}{c}\text { Cut1 } \\
(800-1730 \mathrm{pb})\end{array}$ \\
\hline A-000 & 0 & 0 & 0 \\
B-001 & 0 & 0 & 1 \\
C-011 & 0 & 1 & 1 \\
D-111 & 1 & 1 & 1 \\
E-010 & 0 & 1 & 0 \\
F-110 & 1 & 1 & 0 \\
G-100 & 1 & 0 & 0 \\
H-101 & 1 & 0 & 1 \\
\hline
\end{tabular}

Ket: 0 , tidak ada pita DNA; dan 1, ada pita DNA.

Tabel 4 Keparahan penyakit blas daun di Kecamatan Kabupaten Maros

\begin{tabular}{|c|c|c|c|c|c|}
\hline Lokasi & $\begin{array}{c}\text { Posisi koordinat (latitude } \\
\text { dan longitude) }\end{array}$ & Varietas & $\begin{array}{l}\text { Umur } \\
\text { (HST) }\end{array}$ & $\begin{array}{c}\text { Keparahan penyakit } \\
(\%)\end{array}$ & Kategori* \\
\hline $\begin{array}{l}\text { Kec. } \\
\text { Bantimurung }\end{array}$ & $\begin{array}{c}\text { Lat. } 4^{\circ} 57^{\prime} 45^{\prime \prime} \\
\text { Long. } 119^{\circ} 36^{\prime} 45^{\prime \prime}\end{array}$ & Inpari 4 & 75 & 18.33 & Sedang \\
\hline Kec. Simbang & $\begin{array}{c}\text { Lat. } 5^{\circ} 1^{\prime} 3^{\prime \prime} \\
\text { Long. } 119^{\circ} 38^{\prime} 57^{\prime \prime}\end{array}$ & Mekongga & 70 & 42.12 & Berat \\
\hline $\begin{array}{l}\text { Kec. Maros } \\
\text { Baru }\end{array}$ & $\begin{array}{c}\text { Lat. } 5^{\circ} 0^{\prime} 11^{\prime \prime} \\
\text { Long. } 119^{\circ} 32^{\prime} 58^{\prime \prime}\end{array}$ & Mekongga & 41 & 23.33 & Sedang \\
\hline $\begin{array}{l}\text { Kec. } \\
\text { Moncongloe }\end{array}$ & $\begin{array}{c}\text { Lat. } 5^{\circ} 6^{\prime} 32^{\prime \prime} \\
\text { Long. } 119^{\circ} 32^{\prime} 18^{\prime \prime}\end{array}$ & Ciherang & 50 & 10.46 & Ringan \\
\hline Kec. Tanralili & $\begin{array}{c}\text { Lat. } 5^{\circ} 6^{\prime} 42^{\prime \prime} \\
\text { Long. } 119^{\circ} 36^{\prime} 42^{\prime \prime}\end{array}$ & Inpari 7 & 52 & 6.57 & Ringan \\
\hline $\begin{array}{l}\text { Kec. } \\
\text { Tompobulu }\end{array}$ & $\begin{array}{c}\text { Lat. } 5^{\circ} 8^{\prime} 19^{\prime \prime} \\
\text { Long. } 119^{\circ} 41^{\prime} 43^{\prime \prime}\end{array}$ & Ciherang & 70 & 9.53 & Ringan \\
\hline Kec. Mandai & $\begin{array}{c}\text { Lat. } 5^{\circ} 6^{\prime} 37^{\prime \prime} \\
\text { Long. } 119^{\circ} 31^{\prime} 47^{\prime \prime}\end{array}$ & Ciherang & 70 & 7.96 & Ringan \\
\hline Kec. Lau & $\begin{array}{c}\text { Lat. } 4^{\circ} 59^{\prime} 7^{\prime \prime} \\
\text { Long. } 119^{\circ} 34^{\prime} 15^{\prime \prime}\end{array}$ & Inpari 4 & 75 & 17.22 & Sedang \\
\hline
\end{tabular}

*Kategori berdasarkan Akhsan dan Palupi (2015)

pada var. Inpari-4 75 HST (18.33 \%) dan di Kecamatan Lau pada var. Inpari-4 75 HST $(17.33 \%)$ dengan kategori sedang. Kategori ringan terdapat di 4 kecamatan lainnya, yaitu di Kecamatan Tanralili pada var. Inpari-7 52 HST (6.57\%), di Kecamatan Mandai pada var. Ciherang 70 HST (9.53\%), di Kecamatan Tompobulu var. Ciherang 70 HST (7.56\%) dan di Kecamatan Moncongloe pada var. Ciherang 50 HST (10.46\%).

\section{Analisis Gen Virulensi Cendawan P. oryzae}

Sebanyak 15 isolat $P$. oryzae diamplifikasi menggunakan 3 jenis primer spesifik gen virulensi. Sebanyak 8 ioslat berhasil diamplifikasi masing-masing menggunakan primer $P w l 2$ dan Erg2, dan sebanyak 5 isolat berhasil diamplifikasi menggunakan primer Cut1. Ukuran pita DNA gen virulensi yang teramplifikasi dari setiap isolat sangat bervariasi (Gambar 1). Selanjutnya hasil visualisasi pita DNA pada gel agarosa elektroforesis digunakan untuk skoring, yaitu skor 1 bila tampak pita DNA dan skor 0 bila tidak ada pita DNA. Hasil elektoforesis yang merupakan representasi masing-masing haplotipe berdasarkan pengelompokan kombinasi ketiga jenis gen (Erg2, Pwl2 dan Cut 1) diperoleh sebanyak 5 haplotipe meliputi haplotipe A-000 (4 isolat), haplotipe C-011 (3 
isolat), haplotipe D-111 (2 isolat), haplotipe bervariasi. Perbedaan keparahan penyakit blas F-110 (3 isolat) dan haplotipe G-100 (3 isolat). dipengaruhi oleh ketahanan masing-masing Tidak ditemukan haplotipe B-001, E-010 dan varietas dan umur tanaman, terutama pada H-101 pada isolat $P$. oryzae yang dianalisis varietas yang memiliki respon rentan atau (Tabel 5).

\section{PEMBAHASAN}

Survei keparahan penyakit blas yang dilakukan pada tanaman padi sawah di Kabupaten Maros menunjukkan data yang agak tahan diketahui bahwa semakin tua umur tanaman maka tingkat keparahan penyakit semakin meningkat. Menurut Akhsan dan Palupi (2015) semakin tua umur tanaman maka jumlah daun tanaman dan anakan padi semakin banyak menyebabkan kelembapan mikro di sekitar tanaman padi semakin meningkat.

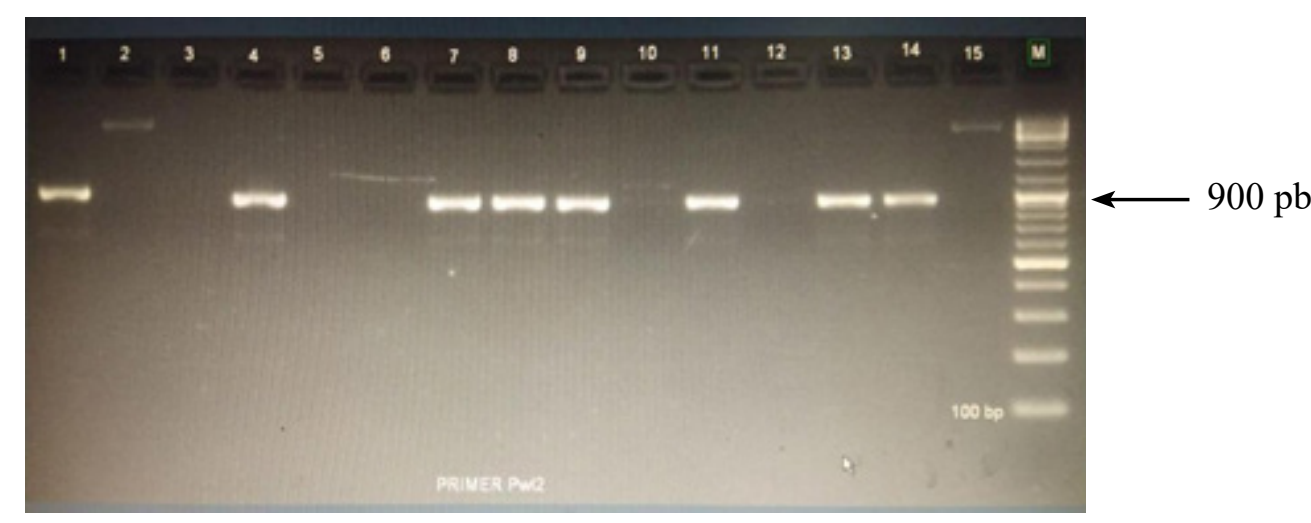

a
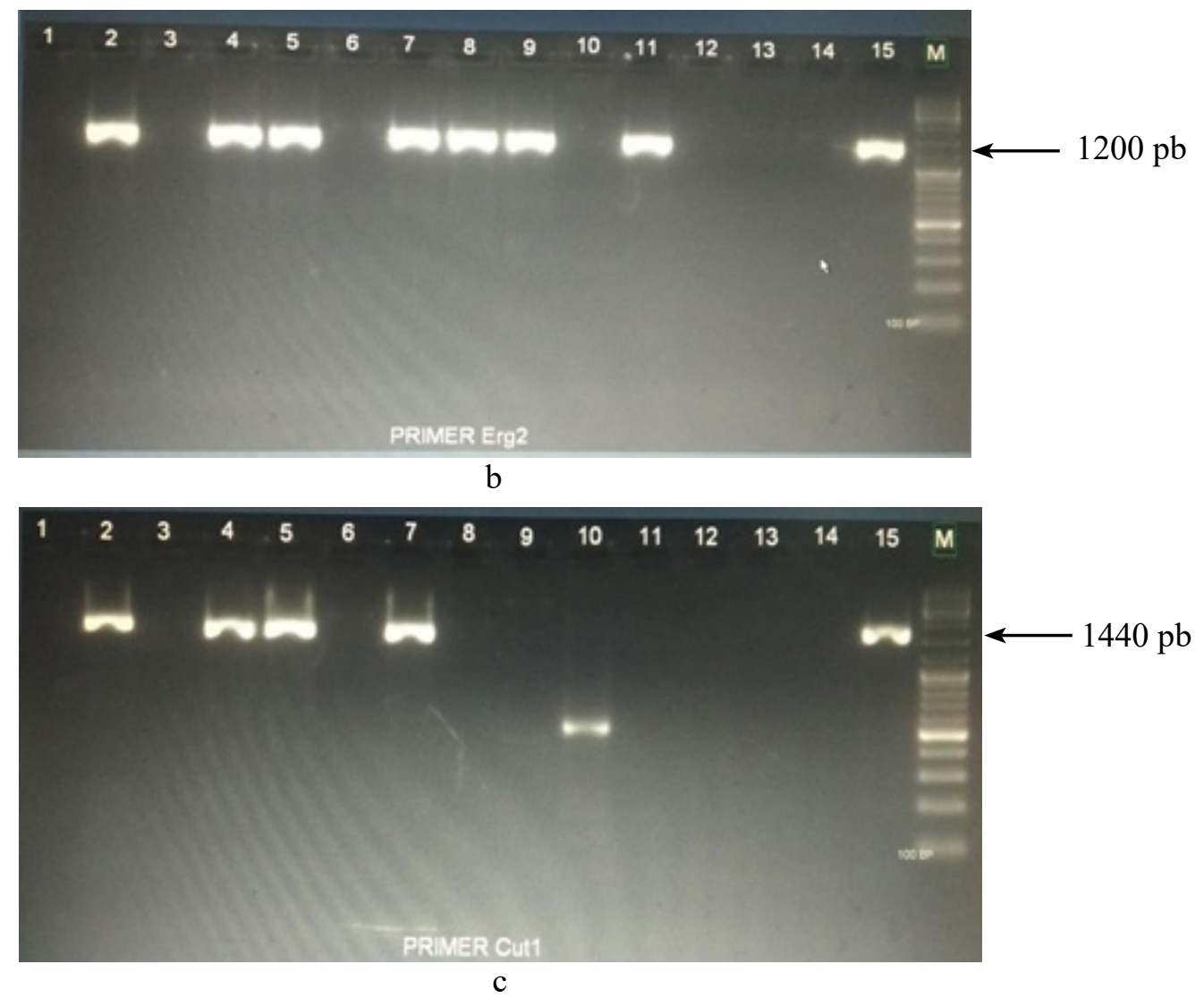

Gambar 1 Amplifikasi DNA genomik Pyricularia oryzae menggunakan 3 jenis primer spesifik gen virulensi. a, Primer Pwl2; b, Primer Erg2; dan Primer Cut1. M, DNA ladder 100 pb; No. 1-15, Isolat P. oryzae. 
Tabel 5 Haplotipe cendawan Pyricularia oryzae berdasarkan pola amplikon 3 gen virulensi yang ditemukan di Kecamatan Kabupaten Maros

\begin{tabular}{lcccc}
\hline \multirow{2}{*}{ Kode isolat } & \multicolumn{3}{c}{ Keberadaan amplikon } & Haplotipe \\
\cline { 2 - 4 } & $\begin{array}{c}\text { Pwl2 } \\
(800-900 \mathrm{pb})\end{array}$ & $\begin{array}{c}\text { Erg2 } \\
(1440 \mathrm{pb})\end{array}$ & $\begin{array}{c}\text { Cut } 1 \\
(800-1730 \mathrm{pb})\end{array}$ & \\
\hline PoBm1 & 1 & 0 & 0 & G-100 \\
PoBm2 & 0 & 1 & 1 & C-011 \\
PoSb1 & 0 & 0 & 0 & A-000 \\
PoSb2 & 1 & 1 & 1 & D-111 \\
PoSb3 & 0 & 1 & 1 & C-011 \\
PoSb4 & 0 & 0 & 0 & A-000 \\
PoMb1 & 1 & 1 & 1 & D-111 \\
PoMb2 & 1 & 1 & 0 & F-110 \\
PoM11 & 1 & 1 & 0 & F-110 \\
PoM12 & 0 & 0 & 0 & A-000 \\
PoT11 & 1 & 1 & 0 & F-110 \\
PoT12 & 0 & 0 & 0 & A-000 \\
PoTb1 & 1 & 0 & 0 & G-100 \\
PoMd1 & 1 & 0 & 0 & G-100 \\
PoLu1 & 0 & 1 & 1 & C-011 \\
\hline
\end{tabular}

Ket: 0, Tidak ada pita DNA; dan 1, Ada pita DNA.

Hal ini memberi kondisi optimum pada patogen untuk terus berkembang. Berdasarkan keparahan penyakit blas di lapangan, respon varietas dibedakan atas ringan (var. Ciherang dan Inpari-7), sedang (var. Inpari-4) dan berat-sedang (var. Mekongga). Terkait dengan ketahanan varietas, hasil yang diperoleh sesuai dengan penelitian sebelumnya mengenai hubungan antara ketahanan suatu varietas terhadap serangan blas padi. Padi var. Ciherang merupakan varietas yang tahan terhadap penyakit blas daun (Akhsan dan Palupi 2015). Intensitas serangan blas pada var. Ciherang di lokasi endemik lebih rendah pada blas daun tetapi serangannya lebih tinggi pada blas leher (Suganda et al. 2016). Padi varietas Sintanur, Pandan Wangi, Ciherang dan Mekongga yang ditanam oleh petani di Kabupaten Pringsewu memiliki sifat ketahanan yang sama, yaitu medium tahan (moderate) terhadap penyakit blas daun, namun rentan terhadap blas leher malai (Adrian 2018). Hal senada dilaporkan oleh Yulianto (2009) bahwa padi var. Mekongga merupakan varietas agak tahan. Rodrigues et al. (2004) melaporkan varietas padi yang tahan cenderung menghambat pembentukan spora cendawan blas dengan memproduksi fitoaleksin tertentu sebagai akibat interaksi antara patogen dan tanaman padi.

Ketinggian wilayah di lokasi pengamatan dan pengambilan sampel berkisar 10-600 $\mathrm{m}$ dpl (BPS 2019). Berdasarkan data online Badan Stasiun Meteorologi, Klimatologi dan Geofisika (BMKG) tahun 2019 rata-rata suhu udara dan kelembapan bulanan di Kabupaten Maros ialah $27.22{ }^{\circ} \mathrm{C}$ dan $74.25 \%$. Kondisi tersebut menguntungkan bagi perkembangan penyakit blas. Pyricularia oryzae berkembang optimal pada kisaran suhu $24-28{ }^{\circ} \mathrm{C}$ dan kelembapan udara mencapai 90\% (IRRI 2010). Perkembangan penyakit blas dipengaruhi oleh banyak faktor termasuk lingkungan,yaitu iklim makro dan mikro berupa musim, kelembapan dan suhu, kesuburan tanah, virulensi patogen dan ketahanan varietas (Santoso dan Nasution 2008).

Isolat cendawan blas yang diisolasi dari lahan pertanaman padi terinfeksi penyakit blas di 8 kecamatan Kabupaten Maros menunjukkan keragaman yang tinggi (8 haplotipe) dan mayoritas cendawan $P$. oryzae yang diuji memiliki ketiga gen yang terlibat dalam proses patogenisitas. Bila 
dibandingkan dengan penelitian Rianingsih (2017) dan Izha (2018), hasil penelitian ini menemukan jumlah dan jenis haplotipe yang lebih beragam di Kabupaten Maros. Analisis molekuler 10 isolat $P$. oryzae oleh Rianingsih (2017) dari Kabupaten Bone, Maros dan Gowa menemukan 3 haplotipe, yaitu C-011, E-010 dan F-110; dengan haplotipe C-011 bersifat dominan. Analisis molekuler yang dilakukan Izha (2018) terhadap 10 isolat $P$. oryzae dari Kabupaten Pinrang menemukan 2 haplotipe yaitu F-110 (8 isolat) dan G-100 (2 isolat).

Jika dikaitkan data hasil analisis gen terkait virulensi pada isolat-isolat uji menggunakan metode SCAR dengan tingkat keparahan penyakit blas di 8 kecamatan Kabupaten Maros maka terdapat hubungan antara kategori tingkat keparahan serangan blas dengan jumlah dan haplotipe yang diperoleh. Haplotipe terbanyak dari isolat patogen ditemukan pada lokasi dengan tingkat keparahan penyakit kategori berat. Sebanyak 4 isolat dengan 3 haplotipe yang ditemukan di Kecamatan Simbang memiliki tingkat keparahan penyakit blas kategori serangan berat. Jumlah isolat relatif lebih sedikit ditemukan pada lokasi yang memiliki tingkat keparahan kategori sedang dan ringan (1-2 isolat) daripada di lokasi yang memiliki tingkat keparahan penyakit blas kategori berat. Secara umum isolat yang diperoleh pada lokasi dengan kategori keparahan sedang lebih banyak daripada kategori ringan. Haplotipe yang berbeda ditemukan pada 2 isolat dalam 1 lokasi seperti haplotipe G-100 dan C-011 ditemukan di Kecamatan Bantimurung, haplotipe D-111 dan F-110 ditemukan di Kecamatan Maros Baru dan haplotipe A-000 dan F-110 ditemukan di Kecamatan Moncongloe

Perbedaan agroekologi sumber isolat P. oryzae dapat menyebabkan diferensiasi yang besar dalam sidik jari DNA genomik cendawan dengan marka MGR586 (Chen et al. 1995). Agrios (1988) dalam Lestari et al. (2014) mengemukakan bahwa lingkungan dapat memengaruhi ketersediaan inokulum, tingkat pertumbuhan patogen, daya tahan hidup patogen dan kerentanan genetik inang serta arah dan jarak penyebaran patogen.
Isolat yang mengandung 1 atau 2 gen virulen tidak stabil kemungkinan sering mengalami mutasi spontan yang berpengaruh cukup tinggi terhadap virulensinya (Lestari et al. 2014). P. oryzae yang mengalami gen dengan frekuensi mutasi normal menunjukkan bahwa ketidakstabilan genetik dapat memengaruhi bagian tertentu genom $P$. oryzae dan efeknya bervariasi tergantung ras (Valent 1997). Dilaporkan oleh Valent dan Chumley (1994) bahwa gen virulen, termasuk $P$ wl 2 tidak stabil. Dalam penelitian ini, isolat $P$. oryzae yang mengandung satu atau lebih gen virulen tidak stabil seperti haplotipe D-111, F-101 dan G-100.

Pola pita DNA dari 15 isolat P. oryzae yang dianalisis berdasarkan primer penyandi gen virulensi ( $P$ wl $2, E r g 2$ dan Cut 1$)$ menggunakan metode SCAR menghasilkan 5 haplotipe, yaitu A-000 (4 isolat); C-011 (3 isolat); D-111 (2 isolat); F-110 (3 isolat); dan G-100 (3 isolat). Gen yang paling besar ditemukan proporsinya ialah gen $P w l 2$ dan Erg2 masingmasing $(53.33 \%)$ selanjutnya Cut1 $(26.67 \%)$. Haplotipe C-011 cenderung ditemukan pada varietas Inpari-4, haplotipe D-111 pada varietas Mekongga dan haplotipe G-100 pada varietas Ciherang. Hasil penelitian ini dapat menjadi acuan bagi pemulia tanaman dalam mengembangkan varietas unggul tahan.

\section{DAFTAR PUSTAKA}

Adrian L. 2018. Pengaruh varietas dan paket pemupukan N, P dan K terhadap intensitas penyakit blas (Pyricularia oryzae Cav.) serta produksi padi [disertasi]. Bandar Lampung (ID): Universitas Lampung.

Akhsan N, Palupi PJ. 2015. Pengaruh waktu terhadap intensitas penyakit blas dan keberadaan spora Pyricularia grisea (Cooke) Sacc. pada lahan padi sawah (Oryzae sativa) di Kecamatan Samarinda Utara. Ziraa'ah Majalah Ilmiah Pertanian. 40(2):114-122.

[BMKG] Badan Meteorologi Klimatologi dan Geofisika. 2019. Data online BMKG. http://dataonline.bmkg.go.id/akses_data [diakses 28 Desember 2019]. 
[BPS] Badan Pusat Statistik. 2019. Kabupaten Maros dalam angka 2019. Badan Pusat Statistik Kabupaten Maros. https:// maroskab.bps.go.id/publication/2019 /08/16/29239258c554034ae6c0fc79/ kabupaten-maros-dalam-angka-2019.html [diakses 20 Maret 2020].

[BPTPH Sulsel] Balai Proteksi Tanaman Pangan dan Hortikultura Sulawesi Selatan. 2014. Laporan serangan organisme pengganggu tanaman Sulawesi Selatan musim tanam 2004-2013. Pemerintah Daerah Provinsi Sulawesi Selatan.

Bonman JM, Vergel De Dios TI, and Khin MM, 1986. Physiologic specialization of Pyricularia oryzae in the Philippines. Plant Dis. 70:767-769. DOI: https://doi. org/10.1094/PD-70-767.

Chen D, Zeigler RS, Leung H, Nelson RJ. 1995. Population structure of Pyricularia grisea at two screening sites in the Philippines. Phytopathology. 85:1011-1020. DOI: https://doi.org/10.1094/Phyto-85-1011.

Direktorat Jenderal Tanaman Pangan. 2015. Laporan akuntabilitas kinerja instansi pemerintah - Direktorat Jenderal Tanaman Pangan Tahun 2015. http:// tanamanpangan.pertanian.go.id/assets/ front/uploads/document/LAKIP_2015 DITJEN_TANAMAN_PANGA $\bar{A}$ N.pdf [diakses $1 \overline{4}$ November 2019].

Fukuta Y, Xu D, Kobayashi N, Jeanie M, Yanoria T, Hairmansis A, Hayashi N. 2009. Genetic characterization of universal differential varieties for blast resistance developed under the IRRI-Japan collaborative research project unsing DNA markers in rice (Oryza sativa L.). JIRCAS Working Report. 63:35-68.

Hayashi N, Fukuta Y. 2009. Proposal for a new international system of differentiating races of blast (Pyricularia oryzae Cavara) by using LTH monogenic lines in rice (Oryza sativa L.). JIRCAS Working Report. 63:11-15

IRRI. 2013. Standart Evaluation System for Rice. $5^{\text {th }}$ d. Los Banos (PH): IRRI.

IRRI. 2010. Rice blast. rice science for a better world. http://www. knoledgebank.irri.org/ [diakses 9 Agustus 2019].
Izha MNY. 2018. Karakteristik morfologi, penyebaran ras dan analisa gen virulensi pada isolat-isolat Pyricularia oryzae (teleomorph: Magnaporthe oryzae) dari Kabupaten Pinrang [tesis]. Makassar (ID): Universitas Hasanuddin.

Kang S, Lee YH. 2000. Population structure and race variation of the rice blast fungus. Plant Pathol J. 16:1-8.

Leung H,Nelson RJ,LeachJE.1993.Population structure of plant pathogenic fungi and bacteria. Adv Plant Pathol.10:157-205.

Lestari P, Wawan, Priyatno, TP, Enggarini W, Reflinur dan Suryadi Y. 2014. Isolasi, identifikasi dan karakterisasi cendawan blas Pyricularia oryzae hasil rejuvenasi. Buletin Plasma Nutfah. 20(1):19-26. DOI: https://doi.org/10.21082/blpn.v20n1.2014. p19-26.

Reflinur, Bustamam M, Widyastuti U, Aswidinnoor H. 2005. Keragaman genetik cendawan Pyricularia oryzae berdasarkan primer spesifik gen virulensi. J Biotek Pertanian. 10:55-60.

Rianingsih. 2017. Studi keragaman ras Isolat Pyricularia oryzae Cavara penyebab penyakit blas pada tanaman padi dari beberapa Kabupaten di Sulawesi Selatan [tesis]. Makassar (ID): Universitas Hasanuddin.

Rodrigues FA, McNally DJ, Datnoff LE, Jones JB.2004. Siliconenhancestheaccumulation of diterpenoid phytoalexins in rice: a potential mechanism for blast resitance. Phytopath. 94:177-183. DOI: https://doi. org/10.1094/PHYTO.2004.94.2.177.

Santoso, Nasution A. 2008. Pengendalian penyakit blas dan penyakit cendawan lainnya. Di dalam Darajat AA, Setyono A, Makarim AK dan Hasanuddin A (Ed). Padi Inovasi Teknologi, Buku Padi 2. Sukamandi (ID): Badan Penelitian dan Pengembangan Pertanian.

Scardaci SC, Webster RK, Greer CA, Hill JE, Williams JG, Mutters RG, Brandon DM, McKenzie KS, Oster JJ. 1997. Rice blast: a new disease in California. Agronomy Fact Sheet Series 1997-2. Davis (US): Department of Agronomy and Range Science, University of California. 1:2-5. 
Skamnioti P, Gurr SJ. 2009. Against the grain: safeguarding rice from rice blast disease. Trends in Biotechnology. 27: 141-150. DOI: https://doi.org/10.1016/j. tibtech.2008.12.002.

Soubabere O, Jorge V, Notteghem JL, Lebrun MH, Tharreau D. 2005. Sequence characterized amplified region markers for the rice blast fungus, Magnaporthe grisea. Molecular Ecology Notes. 1:1921. DOI: https://doi.org/10.1046/j.14718278.2000.00008.x.

Srivastava D, Shamim Md, Kumar D, Pandey P, Khan NA and Singh KN. 2014. Morphological dan molecular characterization of Pyricularia oryzae causing blast diseases in rice (Oryza sativa) from North India. Inter J Sci Res Pub. 4(7):1-9.

Suganda T, Yulia E, Widiantini F, Hersanti. 2016. Intensitas penyakit blas (Pyricularia oryzae Cav.) pada padi varietas Ciherang di lokasi endemik dan pengaruhnya terhadap kehilangan hasil. Jurnal Agrikultura. 27(3):154-159. DOI: https://doi. org/10.24198/agrikultura.v27i3.10878.

Taheri P, Irannejad A. 2014. Genetic structure of various Magnaporthe oryzae populations in Iran and Uruguay. Aus Plant Pathol. 43:287-297. DOI: https:// doi.org/10.1007/s13313-013-0269-0.
Utami DW, Aswidinnoor H, Moelyopawiro S, Hanarida I dan Reflinur. 2006. Pewarisan ketahanan penyakit blas (Pyricularia grisea Sacc.) pada persilangan Padi IR64 dengan Oryza rufipogon Griff. J. Hayati. 13(3):107-112. DOI: https://doi. org/10.1016/S1978-3019(16)30302-3.

Valent B. 1997. The rice blast fungus Magnaporthe grisea. Di dalam Carroll GC, Tudzynoski P (Ed.). The Mycota $V$ : Plant Relationships Part B. Berlin (DE): Springer-Verlag. hlm 37-54. DOI: https:// doi.org/10.1007/978-3-642-60647-2_3.

Valent B, Chumley FG. 1994. Avirulence genes and mechanisms of genetic instability in rice blast fungus. Di dalam Zeigler RS, Leong SA, and Teng PS (Ed). Rice Blast Disease. Wallingford (UK): CAB International. hlm 111-134.

Wang X, Lee S, Wang J, Ma J, Bianco T, and Jia Y. 2014. Current advances on genetic resistance to rice blast disease. Chapter 7. Di dalam Yan W and Bao J (Ed). RiceGermplasm, Genetics and Improvement. http:// www.intechopen.com/books/ricegermplasmgenetics- and-improvement/ current-advances-ongenetic- resistanceto-rice-blast-disease [diakses 15 Januari 2020].DOI:https://doi.org/10.5772/56824.

Yulianto. 2009. Penyakit blas ancaman serius lahan tadah hujan. Warta Inovas. 2(2):18-19. 